\title{
Lectotypification of three Iberian endemic species belonging to monotypic genera described by Cosson
}

\author{
Antoni Buira*, Alejandro Quintanar \& Carlos Aedo \\ Department of Biodiversity and Conservation, Real Jardín Botánico de Madrid CSIC, Plaza de Murillo., 2, 28014-Madrid, Spain; abuira@rjb.csic.es
}

\begin{abstract}
Buira, A., Quintanar, A. \& Aedo, C. 2015. Lectotypification of three Iberian endemic species belonging to monotypic genera described by Cosson. Anales Jard. Bot. Madrid 72(2): e024.

Three lectotypes are here designated for Euzomodendron bourgaeanum Coss., Guiraoa arvensis Coss. and Laserpitium scabrum Cav. (Guillonea scabra (Cav.) Coss.), whose genera are monospecific and endemic to the Iberian Peninsula. The selected types of the two former species are kept at $\mathrm{P}$ and belong to Cosson's personal herbarium, whilst the last one is kept at MA and belongs to the historical herbarium of Cavanilles.
\end{abstract}

Keywords: endemic genera, Euzomodendron, Guiraoa, Guillonea, typification, Cosson

\section{INTRODUCTION}

The Iberian flora includes 24 endemic or subendemic genera, most of them monospecific (Aedo \& al., 2013). During the development of the Flora iberica project, we realised that many of these genera had yet to be typified. Since the monospecific genus Lapiedra Lag. has already been typified by Estebánez \& al., 2008, we have focused, in the present survey, on three endemic genera originally described by Ernest Saint Charles Cosson (1851-1852) as monotypic: Euzomodendron Coss. (1852: 144), Guillonea Coss. (1851: 109), and Guiraoa Coss. (1851: 97). According to the ICN (Art. 40.3), the lectotypification of each single species cited within these three genera (E. bourgaeanum Coss. (1852: 145), G. scabra (Cav.) Coss. (1851: 109), and G. arvensis Coss. (1851: 98), respectively) implicitly entails their typification. However, none of them have yet been typified. Therefore, the respective typifications are essential to firmly establish the nomenclature of such names.

Euzomodendron bourgaeanum Coss., Notes Pl. Crit.: 144 (1852)

The genus Euzomodendron belongs to the Cruciferae and E. bourgaeanum is hitherto the only known species within this genus. It is a chamaephyte occurring through a small sub-desertic area in southeastern Spain that ranges from Gádor to the Alhamilla Mountains in the province of Almería. This species grows on marly or gipsaceous scarcely vegetated badlands, between 100 and $500 \mathrm{~m}$ above sea level. Flowering occurs between March and May, but it can stretch on from December to August depending on the rainfall of the year (López González, 1993). The main characters of E. bourgaeanum are: dehiscent, glabrous or sparsely hairy

\section{Resumen}

Buira, A., Quintanar, A. \& Aedo, C. 2015. Lectotipificación de tres especies endémicas de la Peninsula lbérica, pertenecientes a un género monotípico descrito por Cosson. Anales Jard. Bot. Madrid 72(2): e024.

Se designan los lectótipos de Euzomodendron bourgaeanum Coss., Guiraoa arvensis Coss. y Laserpitium scabrum Cav. (Guillonea scabra (Cav.) Coss.), cuyos géneros son monoespecíficos y endémicos de la Península Ibérica. Los tipos seleccionados para las dos primeras especies se encuentran en $\mathrm{P}$ y pertenecen al herbario personal de Cosson, mientras que el de la última se encuentra en MA y pertenece al herbario histórico de Cavanilles.

Palabras clave: géneros endémicos, Euzomodendron, Guiraoa, Guillonea, tipificación, Cosson

siliqua, with the lower part much longer than the upper one; usually more than 4 seeds per locule, conspicuously winged seeds, and generally divided leaves.

Molecular studies (Warwick \& Black, 1994; Crespo $\&$ al., 2000) pointed out a close relationship between Euzomodendron and Vella Linnaeus (1753: 641). Although molecular data plus an analysis of unique shared features (e.g. lengthy connate inner stamens, navicular fruit valves and basic chromosome number $x=17)$ led Warwick \& Al-Shehbaz (1998) to unite both genera in Vella, Crespo \& al. (2000) recognized Euzomodendron as an independent genus sister to Vella on the basis of combined parsimony analysis of nuclear ribosomal internal transcribed spacer (ITS) and morphologic characters. These results were also supported by some morphological autapomorphies of Euzomodendron (lengthy petiolate and pinnate leaves, long, linear-lanceolate, and flattened siliqua) as well as other morphological characters (lacking stipules, flattened and broadly winged seeds, which are numerous in each locule).

Despite being included as an additional species in this genus, Euzomodendron longirostre (Boiss.) Pau (1922: 20) was later considered to belong to the genus Coincya (C. longirostra (Boiss.) Greuter \& Burdet in Greuter \& Raus (1983: 87); Leadlay, 1993).

\section{TYPIFICATION}

Ind. loc.: "In calcareis salsuginosis Hispaniae orientalis australioris, in ditione Almeriensi ad basim montis Sierra de Gador inter oppida Santa Fe et Huesica (E. Bourgeau, pl. Esp. n. $\left.{ }^{\circ} 1058\right) . "$

Type: SPAIN. Almería. Between Santa Fe de Mondújar and Huécija (Huesica?), 36 $6^{\circ} 58^{\prime} \mathrm{N}, 2^{\circ} 31^{\prime} \mathrm{W}$, E. Bourgeau s.n., 7 May 1851 (Lectotype designated here: P 5341211, 

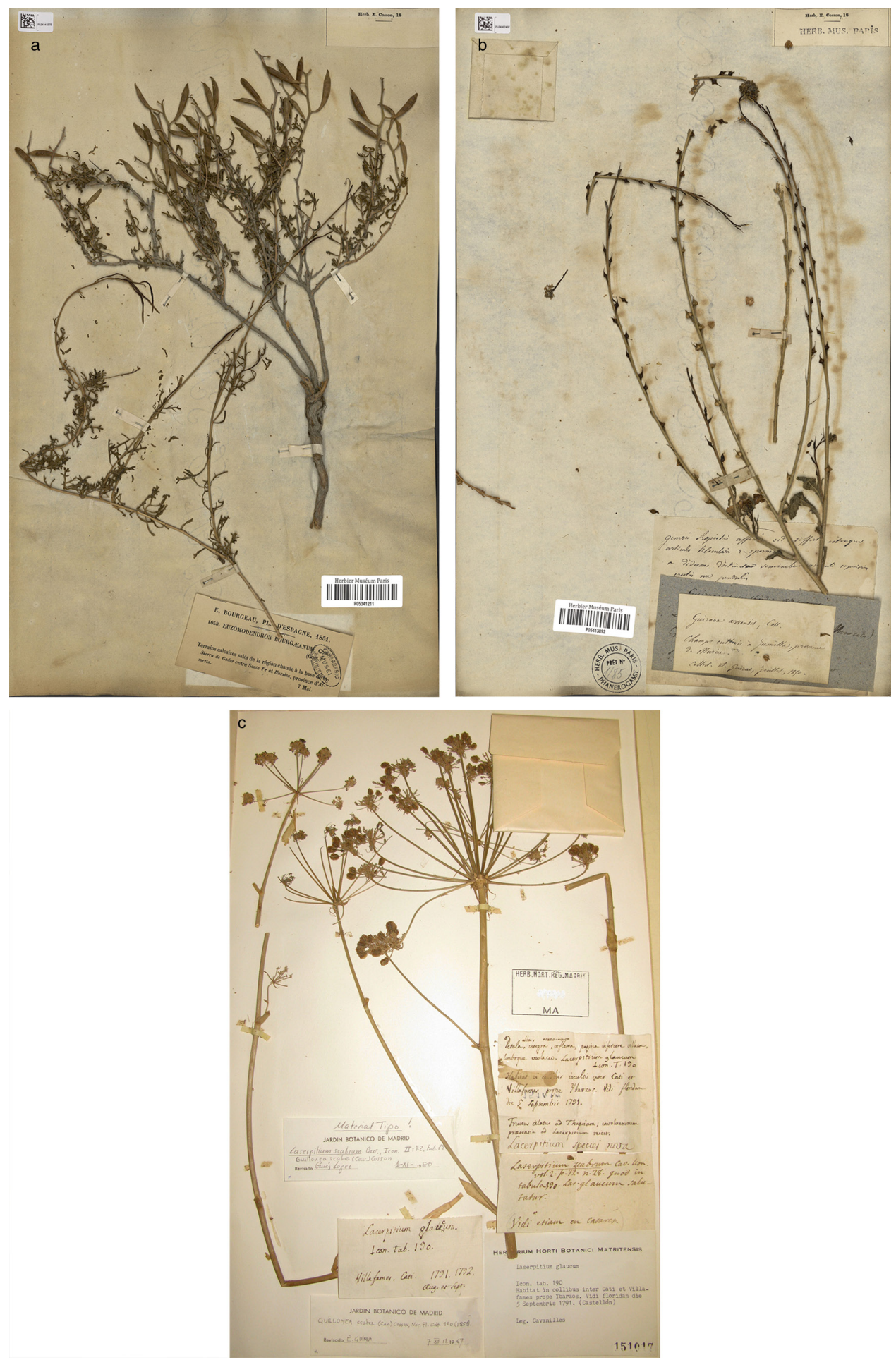

Fig. 1. a, lectotype of Euzomodendron bourgaeanum (P 5341211) (http://coldb.mnhn.fr/catalognumber/mnhn/p/p05341211); b, lectotype of Guiraoa arvensis (P 5413892) (http://coldb.mnhn.fr/catalognumber/mnhn/p/p05413892); c, lectotype of Laserpitium scabrum (current name Guillonea scabra) (MA 151017).

Fig. 1a; isolecto-: P 4655816 photo!, P 5341210 photo!, B 10 0249565 photo!, K 653945 photo!, K 653946 photo!).

Ic.: Gómez-Campo in Castrov. \& al. (eds.), Fl. Iber. 3: 345 lám. 128.

Current accepted name: Euzomodendron bourgaeanum Coss.

The protologue of the species refers to number 1058 of the collection "Plantes d'Espagne" of 1851, collected by E. Bourgeau. Several specimens of this gathering were located at $\mathrm{P}, \mathrm{B}$, and $\mathrm{K}$ herbaria. We choose as lectotype of E. bourgaeanum the specimen kept at $\mathrm{P}$ (P 5341211), which belonged to E.S.-Ch. Cosson's personal herbarium. It consists of two fructified fragments which unequivocally belong to E. bourgaeanum. The rest of the duplicates have also mature fruits and are well conserved. 


\section{Guiraoa arvensis Coss., Notes Pl. Crit. 98 (1851)}

Guiraoa comprises the Iberian endemic of Cruciferae, G. arvensis. This species grows on ruderal and uncultivated areas, generally on gipsaceous soils, between 30 and $300 \mathrm{~m}$ above sea level, in southeast Spain, from Alicante to Almería, with a further single northern population in Valencia. Its flowers usually bloom between March and May (Gómez Campo, 1993). The morphology of the fruits of Guiraoa clearly differentiates this genus from other Cruciferae: silicula has two well differentiated carpels, the lower one is obconic or cylindrical, dehiscent and generally bilocular with a single seed per locule, while the upper one is globular, conspicuously bigger than the lower one, with eight winged ribs, indehiscent, and bilocular with one or two seeds.

\section{TYPIFICATION}

Ind. loc.: "In arvis regni Murcici, prope Jumilla (A. Guirao)." Type: SPAIN. Murcia. Jumilla, $38^{\circ} 28^{\prime} \mathrm{N}, 1^{\circ} 19^{\prime} \mathrm{W}$, A. Guirao s.n., Jul 1850 (lectotype designated here: P 5413892, Fig. 1b, ex herb. Coss.; isolecto-: P 5413896 photo!).

Ic.: Gómez-Campo in Castrov. \& al. (eds.), Fl. Iber. 3: 434 lám. 162.

Current accepted name: Guiraoa arvensis Coss.

In the protologue of G. arvensis, E.S.-Ch. Cosson (1851) mentioned some material collected by A. Guirao in southeastern Spain. A. Guirao (?-1890) was a Spanish naturalist who was in touch with important botanists of his time, Graells and Willkomm among them. These authorities used their collections from southeastern Spain. His personal herbarium was unfortunately lost, but a considerable extent of it remained within the collections of the aforementioned botanists, nowadays kept at COI and MA.

A specimen from E.S.-Ch. Cosson's personal herbarium collected by A. Guirao on the date and location mentioned in the protologue was located at P herbarium (P 5413892). Among the studied materials, it must be undoubtedly chosen as lectotype of this taxon. Another specimen located at P (P 5413896) is certainly a duplicate. Although it has a printed stencil corresponding to an exsiccata of 1849 , we think it was collected at the same time as the former. Both specimens consist of fructified branches with flowers and well developed fruits which, unequivocally, belong to $G$. arvensis. We also checked any additional specimen collected by A. Guirao and kept at MA, COI and Real Colegio Alfonso XII Herbarium (Carrasco, 2001), but all of them were collected after the date indicated in the protologue of the species.

Laserpitium scabrum Cav., Icon. 2: 72, tab. 190 (1793).

Guillonea belongs to the Umbelliferae family and G. scabra is currently the only species within this genus. It has a wide area in southeastern Spain ranging the coastal provinces from Castellón to Cádiz, including also some inland provinces (Ciudad Real, Jaén, Albacete, Teruel, and Cuenca). This species grows in Mediterranean scrubs, usually dominated by rosemary and thyme, and pine-wood clearings, on calcareousclayey soils, usually between 200 and $1200 \mathrm{~m}$ above sea level. The flowering period is normally between July to October
(Montserrat, 2003). Guillonea scabra was originally described as Laserpitium scabrum by A.J. de Cavanilles (1793: 72). Both genera, Guillonea and Laserpitium, have mericarps with 4 widely winged secondary ribs. Guillonea has densely hairy mericarps with 5 prominent primary ribs and entire ovate petals, while Laserpitium shows little prominent ribs, obovate incised petals, and glabrescent mericarps.

At the same time that E.S.-Ch. Cosson combined G. scabra, he suggested Laserpitium canescens Boiss. could be closely related, even if no formal synonymization was proposed. Later, J.M.C. Lange (1838) considered both as different species within Guillonea, G. scabra and G. canescens (Boiss.) Lange. The current taxonomic treatment (Montserrat, 2003) considers both taxa as subspecies of G. scabra. Guillonea scabra subsp. scabra lives throughout the eastern part of the species distribution area, while G. scabra subsp. canescens (Boiss.) Nyman occupies the southern part. The type of Boissier's taxon was selected by H.M. Burdet \& al. (1991: 590-591), while Cavanilles' taxon remains untypified.

\section{TYPIFICATION}

Ind. loc.: "Habitat in collibus prope Cati, copiose vero in viciniis Villafames."

Type: SPAIN. Castellón. Between Catí and Villafamés, near Els Ibarsos (Ybarzos?), $40^{\circ} 13^{\prime} \mathrm{N}, 0^{\circ} 4^{\prime} \mathrm{W}$, A.J. Cavanilles s.n., 5. Sep.1791 (Lectotype designated here: MA 151017!).

Ic.: P. Monts. in Castrov. \& al. (eds.), Fl. Iber. 10: 382 lám. 122. Current accepted name: Guillonea scabra (Cav.) Coss.

In this case, A.J. Cavanilles' protologue of Laserpitium scabrum included an original illustration of the species. Nevertheless, we located a single original specimen kept at MA that belonged to A.J. Cavanilles' personal herbarium, which has priority as lectotype (ICN art. 9.12). It contains six labels, two of them handwritten by A.J Cavanilles with the species description and the indication of habitat and location. It agrees with the protologue: "Habitat in collibus prope Cati, copiose vero in viciniis Villafames". Another label, written by G. López, notes its identity as type material, although formal typification has not yet been published (Garilleti, 1993). The specimen consists of one inflorescence and infrutescence with well-developed fruits.

\section{ACKNOWLEDGEMENTS}

We thank M. Fernández and C. Baranda from MA Herbarium for their technical support and G. López for his help with the lectotypification of Laserpitium scabrum. This work has been supported by the Spanish Government through the 'Flora Iberica' project (CGL2011-28613-C03-01).

\section{REFERENCES}

Aedo, C., Medina, L. \& Fernández-Albert, M. 2013. Species richness and endemicity in the Spanish vascular flora. Nordic Journal of Botany 31: 478-488. http://dx.doi.org/10.1111/j.1756-1051.2012.00009.x

Burdet, H.M., Charpin, A. \& Jacquemoud, F. 1991. Types nomenclaturaux des taxa ibériques décrits par Boissier ou Reuter. XIII. Solanacées à Violacées. Candollea 46: 579-600.

Carrasco, M.A., Millanes, A.M., Perea, D. \& Rodríguez-Calcerrada, J. 2001. Plantas de D. Ángel Guirao (?-1890) en el Herbario del Real Colegio Alfonso XII de San Lorenzo de El Escorial (Madrid, España). Botanica Complutensis 25: 329-338. 
Cavanilles, A.J. 1793. Icones et descriptiones plantarum, quae aut sponte in Hispania crescunt, aut in hortis hospitantur, vol. 2. Madrid, ex Regia Typographia. $83 \mathrm{pp}$

Cosson, E.S.-Ch. 1849-1852. Notes sur quelques plantes critiques, rares ou nouvelles, et additions a la flore des environs de Paris. Paris, Librairie de Victor Masson. 184 pp.

Crespo M.B., Lledó, M.D., Fay, M.F. \& Chase, M.W. 2000. Subtribe Vellinae (Brassiceae, Brassicaceae): a Combined Analysis of ITS nrDNA Sequences and Morphological Data. Annals of Botany 86: 53-62. http:// dx.doi.org/10.1006/anbo.2000.1157

Garilleti, R. 1993. Herbarium Cavanillesianum. Fontqueria 38: 1-249.

Gómez-Campo, C. 1993. Euzomodendron Coss. In: Castroviejo, S. \& al. (Eds.), Flora iberica 3: 344-346. Madrid.

Gómez-Campo, C. 1993. Guiraoa Coss. In: Castroviejo, S. \& al. (Eds.), Flora iberica 3: 433-435. Madrid.

Gonzalo Estebánez, R., Cabezas, F. \& Aedo, C. 2008. Neotypification of the name Lapiedra martinezii Lag. (Amaryllidaceae). Candollea 63: 205-207.

Greuter, W. \& Raus, T. 1983. Med-Checklist Notulae, 7. Willdenowia 13(1): 79-99
Leadlay, E.A. 1993. Coincya Coss. In: Castroviejo, S. \& al. (Eds.), Flora iberica 10: 400-411. Madrid.

Linnaeus, C. 1753. Species Plantarum. Laurentii Salvii, Holmiae, 1200 pp.

Montserrat, P. 2003. Guillonea Coss. In: Castroviejo, S. \& al. (Eds.), Flora iberica 10: 380-383. Madrid.

Pau, C. 1922. Nueva contribución al estudio de la Flora de Granada. Memòries del Museu de Ciències Naturals de Barcelona. I, $n^{\circ} 1$, sèrie botànica. Barcelona: Museu de Ciències Naturals de Barcelona. 74 pp.

Warwick, S.I. \& Al-Shehbaz, I.A. 1998. Generic evaluation of Boleum, Euzomodendron and Vella (Brassicaceae). Novon 8: 321-325. http:// dx.doi.org/10.2307/3392030

Warwick, S.I. \& Black, L.D. 1994. Evaluation of the subtribes Moricandiinae, Savignyinae, Vellinae, and Zillinae (Brassicaceae, tribe Brassiceae) using chloroplast DNA restriction site variation. Canadian Journal of Botany 72: 1692-1701. http://dx.doi.org/10.1139/b94-208

Associate Editor: Ramón Morales Received: 15-VI-2015 Accepted: 14-VII-2015 